\title{
Integrated approach for the management of white grub and collar rot in groundnut (Arachis hypogaea L.) in South West Haryana
}

\author{
Ram Karan Gaur*, Sushil Sharma, D.V. Pathak and S. S. Dashad ${ }^{1}$ \\ Chaudhary Charan Singh Haryana Agricultural University, Regional Research Station, Bawal - 123501 (Rewari), \\ Haryana (India) \\ ${ }^{1}$ Retired Professor, Chaudhary Charan Singh Haryana Agricultural University, Regional Research Station, Bawal - \\ 123501 (Rewari), Haryana (India) \\ *Corresponding author. E-mail:drramkaran1965@gmail.com
}

Received: May 8, 2016; Revised received: September 29, 2016; Accepted: January 8, 2017

\begin{abstract}
Field experiments were conducted at Chaudhary Charan Singh Haryana Agricultural University, Regional Research Station, Bawal (Rewari), Haryana during Kharif seasons of 2011 and 2012. Fifteen treatments including three insecticides, one fungicide, three antagonists, one amendment and one neem formulation were evaluated in sole and combination treatments as seed dresser where as chlorpyriphos $20 \mathrm{EC}$ and poultry manure were incorporated in soil to find out effective combination for control of collar rot and white grub of groundnut. Minimum disease incidence 0.3 and 0.7 per cent and white grub infestation 1.2 and 1.5 per cent was recorded during 2011 and 2012 with seed treatment of chlorpyriphos 20 EC @ $25 \mathrm{ml} / \mathrm{kg}$ seed + PM $4 @ 10 \mathrm{ml} / \mathrm{kg}$ seed + captan 3g/kg seed followed by imidacloprid 17.8 SL @ $7 \mathrm{ml} / \mathrm{kg}$ seed and chlorpyriphos 20 EC @ $25 \mathrm{ml} / \mathrm{kg}$ seed + Bacillus thuriengensis @ $10 \mathrm{ml}$ $\mathrm{kg}$ seed + captan $3 \mathrm{~g} / \mathrm{kg}$ seed. The yield was significantly (at $5 \%$ level) low $(7.10 \mathrm{q} / \mathrm{ha}$ during 2011 and $6.8 \mathrm{q} / \mathrm{ha}$ during 2012) in control as compared to chlorpyriphos 20 EC + PM-4 + captan treatment (20.20 q/ha during 2011 and $19.80 \mathrm{q} / \mathrm{ha}$ during 2012) which ranked at first place. The seed treated with imidacloprid $17.8 \mathrm{SL} 7 \mathrm{ml} / \mathrm{kg}$ seed also produced good yield in both the years and was rated as second best treatment followed by chlorpyriphos + Bacillus thurengiensis + captan. The results obtained herein provide the foundation for an effective and sustainable programme of management for groundnut white grub and collar rot. Integrated approach having chlorpyriphos 20 EC @ $25 \mathrm{ml} / \mathrm{kg}$ seed, Pseudomonas maltophilia (PM4) @ $10 \mathrm{ml} / \mathrm{kg}$ seed and captan $3 \mathrm{~g} / \mathrm{kg}$ seed was found to be most effective for control of collar rot and white grub infestation in ground nut.
\end{abstract}

Keywords: Arachis hypogaea, Aspergillus niger, Collar rot, Imidacloprid, White grub

\section{INTRODUCTION}

Groundnut (Arachis hypogaea Link) is an important oilseed crop and world's largest source of edible oil. In India, total area underground nut crop for the year 2015 was about 44.46 lakh ha with production of 71.8 lakh tonnes and average yield of about $1615 \mathrm{~kg} / \mathrm{ha}$ (Anon, 2016). India is one of the major exporting countries of groundnut after china. The major constraints in its production are unreliable rainfall pattern, poor germination or early mortality of seedlings due to seed and soil borne diseases or insect pests (Anitha et al., 2005; Sharma and Mehra, 2014; Gangwar et al., 2015). Collar rot (Aspergillus niger) and white grub (Holotrichia consanguinea) are major bottlenecks in almost all groundnut growing states of India. The disease was first reported from India by Jain and Nenra (1952) where as the first occurrence of white grub was recorded from Gujarat in 1957 and later on also in Haryana, Himachal Pradesh, Rajasthan and Punjab. (Atwal and Dhaliwal, 2010). The losses due to the disease have reported to the tune of 13 to 40 per cent
(Sharma and Mehra, 2014) and the white grub has assumed the status of a serious pest in Maharashtra, Gujarat, Rajasthan, Andhra Pradesh, Tamil Nadu, Punjab and Bihar where endemic pockets have developed (Singh et al., 2012; Theurkar et al., 2013; Gangwar et al., 2015). Conventionally, this disease and pest is controlled by seed dressing chemicals, the efficacy of which lasts for 3-4 weeks only (Gangopadhyay et al., 1996; Anitha et aI., 2005; Parakhia and Akbari, 2004; Rakholiya et al., 2012). Combined use of different biocontrol agents or integration of biocontrol agents with other disease management options, with identifiable differences in their mechanisms of action, has improved disease protection and the activity spectrum of biocontrol agents (Jetiyanon and Kloepper, 2002). The use of poultry litters has also been advocated by many workers in checking the soil borne diseases/pests (Raj Kumar and Raja, 2007). In view of significant damage to groundnut by collar rot and white grubs, an attempt was made to curtail this disease and pest through pesticides, amendments, bio-control agents and neem formulation alone and in integration. 


\section{MATERIALS AND METHODS}

Two years field experiments were conducted at Chaudhary Charan Singh Haryana Agricultural University, Regional Research Station, Bawal (Rewari), Haryana located at New Delhi -Jaipur National Highway, No 8 and $90 \mathrm{~km}$ from New Delhi during Kharif 2011 and 2012. The soil of the region are light textured sand and loamy sand with poor fertility and low water holding capacity. The weather remains almost dry from October to mid April except for a few light winter rain showers. Later on, the weather remains dry till mid June with high temperature and evaporative demand for water. The number of rainy days in a year varies from 30 to 40 . Groundnut variety MH 4 was used for study. The seed treatment was given as per treatments just before sowing, spread over the polythene sheets and left overnight for drying. The poultry manure was added in the experimental plots before sowing whereas in another treatment; chlorpyriphos $20 \mathrm{EC}$ was first mixed with sand and then applied in the plots before sowing. In total, there were 15 treatments namely Chlorpyriphos 20EC, 25 $\mathrm{ml} / \mathrm{kg}$ seed $\left(\mathrm{T}^{1}\right)$, Quinalphos $25 \mathrm{EC}, 25 \mathrm{ml} / \mathrm{kg}$ seed $\left(\mathrm{T}^{2}\right)$, Poultry manure, 5t/ha half decomposed $\left(\mathrm{T}^{3}\right)$, Poultry manure, 5t/ha fully decomposed $\left(\mathrm{T}^{4}\right)$, Nimbecidine $0.03 \%, 20 \mathrm{ml} / \mathrm{kg}$ seed $\left(\mathrm{T}^{5}\right)$, Pseudomonas maltophilia - 4 (PM-4), $10 \mathrm{ml} / \mathrm{kg}$ seed $\left(\mathrm{T}^{6}\right)$, Rhizobium $\mathrm{GN}-1,10 \mathrm{ml}\left(\mathrm{T}^{7}\right)$, Pseudomonas fluorescens, $10 \mathrm{ml} / \mathrm{kg}$ seed $\left(\mathrm{T}^{8}\right)$, Bacillus thurengiensis, $30 \mathrm{ml} / \mathrm{kg}$ seed $\left(\mathrm{T}^{9}\right)$, Chlorpyriphos + BT + Captan, $25 \mathrm{ml}+10 \mathrm{ml}+3 \mathrm{~g} / \mathrm{kg}$ seed $\left(\mathrm{T}^{10}\right)$, Chlorpyriphos + PM-4 + Captan, $25 \mathrm{ml}+$ $10 \mathrm{ml}+3 \mathrm{~g} / \mathrm{kg}$ seed $\left(\mathrm{T}^{11}\right)$, Imidacloprid $17.8 \mathrm{SL}, 5 \mathrm{ml} /$ $\mathrm{kg}$ seed $\left(\mathrm{T}^{12}\right)$, Imidacloprid 17.8 $\mathrm{SL}, 7 \mathrm{ml} / \mathrm{kg}$ seed $\left(\mathrm{T}^{13}\right)$, Chlorpyriphos $20 \mathrm{EC}, 5 \mathrm{l} / \mathrm{ha}\left(\mathrm{T}^{14}\right)$, Captan, $3 \mathrm{~g} /$ $\mathrm{kg}$ seed $\left(\mathrm{T}^{15}\right)$, and $\mathrm{T}^{16}$ control (untreated). Sowing was done in the first week of July in both years in a field perennially infested with white grubs and Aspergillus niger following all the recommended agronomic practices (Anonymous, 2009). Treatments were randomized block wise having plot area of $5.0 \times 4.0$ sq. m. and replicated thrice. The observations on per cent plant mortality in groundnut due to white grub and collar rot per plot were recorded at the interval of one week and then cumulative per cent mortality was worked out separately for each treatment. The crop was harvested in second fortnight of October in both the years and yield of each plot was recorded.

\section{RESULTS AND DISCUSSION}

The results depicted in Table 1 indicated that the white grub infestation in groundnut among different treatments ranged from 1.2 to 28.5 during 2011 and 1.5 to 29.5 per cent during 2012 against control where the values were 30.2 and 32.4 per cent, respectively. The minimum cumulative plant mortality $(1.2 \%$ in 2011 and $1.5 \%$ in 2012 ) due to whitegrub was recorded in treatment of chlorpyriphos 20 EC@25 ml $/ \mathrm{kg}$ seed + PM $4 @ 10$ ml $/ \mathrm{kg}$ seed + captan@3 g/kg seed when used as seed dressers. This was followed by imidacloprid 17.8 SL@7ml/kg seed where cumulative plant mortality was observed 1.8 per cent and 1.7 per cent in 2011 and 2012, respectively. The treatment of chlorpyriphos 20 EC@25 ml/kg seed+BT@10 ml/ kg seed+captan@3 g/kg seed was also at par with Chlorpyriphos 20 EC@25 ml /kg seed + PM-4@10 $\mathrm{ml} / \mathrm{kg}$ seed + captan@3 g/kg seed and imidacloprid 17.8 SL@ $7 \mathrm{ml} / \mathrm{kg}$ seed in reducing the damage caused by white grub in both the years. Rest of the treatments were also significantly (at 5\% level) superior over control in terms of per cent cumulative mortality of the plant barring seed treatment with captan. The present finding corroborates with the finding of Anitha et al., (2005) who conducted the study on chemical control of groundnut white grub, Holotrichia serrata and $H$. reynaudi in south-central India. They observed that chlorpyriphos and imidacloprid seed dressing were effective against $H$. serrata at rates as low as 0.6 and $3.5 \mathrm{gm} \mathrm{a.i} / \mathrm{kg}$ seed, respectively. The minimum cumulative plant mortality $(4.98 \%)$ due to white grub in groundnut was recorded over control (88.61\%) when seed dressing and coating of groundnut seed with insecticides clothianidin 50 WDG @ $3 \mathrm{~g} / \mathrm{kg}$ seed (Gangwar et al., 2015). The effectiveness of chlorpyriphos@20 ml/lg seed and imidacloprid, cypermethrin and fenvalerate @ $10 \mathrm{ml} / \mathrm{kg}$ seed each against white grub in pearlmillet was advocated by Chaudhary and Dashad (2002). In a study on the control of white grub, seed treatment of groundnut with imidacloprid 200 SL @ $3 \mathrm{ml} / \mathrm{kg}$ seed resulted in 80.36 per cent control (Singh et al., 2012).

As could be seen from the data (Table 1) that all the treatments were effective in controlling collar rot disease in groundnut. The integration of captan with antagonists and insecticides was superior over sole treatment as the least incidence ( 0.3 during 2011 and 0.7 during 2012) was recorded in treatment with chlorpyriphos 20 EC@25 ml+PM@10 ml + captan3@g/kg seed whereas the figures in control were 10.3 and 9.4 percent during the two years, respectively. This was closely followed by chlorpyriphos20 EC@25 ml+BT@10 $\mathrm{ml}+$ captan@3 g/kg seed. Parakhia and Akbari (2004) observed least collar rot disease incidence in treatment with fungicide (thiram) and antagonists (Pseudomonas sp. and Bacillus). Interestingly, the performance of imidacloprid 17.8 SL@7 gm $/ \mathrm{kg}$ seed was also promising in reducing the disease incidence where it was 3.0 in 2011 and 3.3 per cent in 2012 and was at par the treatment of captan. Decreased collar rot incidence in groundnut with seed treatment of thiram, captan, mancozeb, carbendazim and carboxin has been reported earlier also (Gangopadhyay et al., 1996; Karthikeyan, 1996; Meena and Gangwar, 2011; Rakholiya et al., 2012). 
Table 1. Relative efficacy of different treatments with amendments, insecticides, bio-control agents and fungicide on mortality due to white grub and collar rot in groundnut.

\begin{tabular}{|c|c|c|c|c|}
\hline \multirow[t]{3}{*}{ Treatment/Dose } & \multicolumn{4}{|c|}{ Percent cumulative mortality } \\
\hline & \multicolumn{2}{|c|}{ White grub } & \multicolumn{2}{|c|}{ Collar rot } \\
\hline & 2011 & 2012 & 2011 & 2012 \\
\hline Chlorpyriphos 20EC, $25 \mathrm{ml} / \mathrm{kg}$ seed $\left(\mathrm{T}^{1}\right)$ & $15.00(22.71)$ & $17.20(24.45)$ & $6.7(14.91)$ & $4.7(12.44)$ \\
\hline Quinalphos $25 \mathrm{EC}, 25 \mathrm{ml} / \mathrm{kg}$ seed $\left(\mathrm{T}^{2}\right)$ & $10.00(18.31)$ & $8.10(16.41)$ & $8.0(16.39)$ & $4.7(12.15)$ \\
\hline Poultry manure, $5 \mathrm{t} / \mathrm{ha}$ (half decomposed) $\left(\mathrm{T}^{3}\right)$ & $16.50(23.95)$ & $15.70(23.10)$ & $5.7(13.78)$ & $4.3(11.84)$ \\
\hline Poultry manure, $5 \mathrm{t} / \mathrm{ha}$ (fully decomposed) $\left(\mathrm{T}^{4}\right)$ & $15.50(23.14)$ & $15.50(23.03)$ & $5.0(12.87)$ & $4.0(11.30)$ \\
\hline Nimbecidine $0.03 \%, 20 \mathrm{ml} / \mathrm{kg}$ seed $\left(\mathrm{T}^{5}\right)$ & $24.00(29.31)$ & $25.70(30.41)$ & $7.0(15.32)$ & $4.3(11.80)$ \\
\hline $\begin{array}{l}\text { Pseudomonas maltophilia - } 4 \text { (PM-4), } 10 \mathrm{ml} / \mathrm{kg} \\
\text { seed }\left(\mathrm{T}^{6}\right)\end{array}$ & $16.40(23.82)$ & $15.10(22.77)$ & $4.3(11.92)$ & $3.7(1.99)$ \\
\hline Rhizobium GN-1, $10 \mathrm{ml}\left(\mathrm{T}^{7}\right)$ & $26.80(31.15)$ & $28.20(32.04)$ & $6.7(14.98)$ & $4.0(11.48)$ \\
\hline Pseudomonas fluorescens, $10 \mathrm{ml} / \mathrm{kg} \operatorname{seed}\left(\mathrm{T}^{8}\right)$ & $20.20(26.62)$ & $18.50(25.43)$ & $5.7(13.79)$ & $4.0(11.48)$ \\
\hline Bacillus thurengiensis, $30 \mathrm{ml} / \mathrm{kg}$ seed $\left(\mathrm{T}^{9}\right)$ & $25.50(30.30)$ & $27.70(31.72)$ & $6.7(14.85)$ & $4.3(11.86)$ \\
\hline $\begin{array}{l}\text { Chlorpyriphos + } \mathrm{BT}+\text { Captan, } 25 \mathrm{ml}+10 \mathrm{ml}+ \\
3 \mathrm{~g} / \mathrm{kg} \text { seed }\left(\mathrm{T}^{10}\right)\end{array}$ & $1.75(7.49)$ & $1.90(7.78)$ & $1.3(6.50)$ & $1.0(5.71)$ \\
\hline $\begin{array}{l}\text { Chlorpyriphos + PM-4 + Captan, } 25 \mathrm{ml}+10 \\
\mathrm{ml}+3 \mathrm{~g} / \mathrm{kg} \text { seed }\left(\mathrm{T}^{11}\right)\end{array}$ & $1.20(6.27)$ & $1.50(6.98)$ & $0.3(3.10)$ & $0.7(4.72)$ \\
\hline Imidacloprid $17.8 \mathrm{SL}, 5 \mathrm{ml} / \mathrm{kg}$ seed $\left(\mathrm{T}^{12}\right)$ & $9.00(17.39)$ & $10.40(18.83)$ & $3.0(9.95)$ & $3.3(10.38)$ \\
\hline Imidacloprid 17.8 SL, $7 \mathrm{ml} / \mathrm{kg}$ seed $\left(\mathrm{T}^{13}\right)$ & $1.70(7.47)$ & $1.80(7.69)$ & $1.7((7.44)$ & $2.3(8.69)$ \\
\hline Chlorpyriphos 20 EC, 5 l/ha $\left(\mathrm{T}^{14}\right)$ & $14.00(21.93)$ & $14.50(22.33)$ & $4.3(11.93)$ & $4.3(12.02)$ \\
\hline Captan, $3 \mathrm{~g} / \mathrm{kg}$ seed $\left(\mathrm{T}^{15}\right)$ & $28.50(32.23)$ & $29.50(32.87)$ & $3.0(9.96)$ & $3.7(10.96)$ \\
\hline Control $\left(\mathrm{T}^{16}\right)$ & $30.20(33.26)$ & $32.40(34.66)$ & $10.3(18.67)$ & $9.4(17.77)$ \\
\hline S. Em. \pm & 0.87 & 1.03 & 0.46 & 0.51 \\
\hline $\mathrm{CD}(\mathrm{P}=0.05)$ & 2.54 & 3.01 & 1.33 & 1.48 \\
\hline
\end{tabular}

Values in parentheses are angular transformed values.

The yield data recorded in different treatments showed that all treatments were significantly superior over control except nimbecidine, Rhizobium GN-1 and Bacillus thurengiensis in both the years (Table 2). The yield was significantly (at 5\% level) low (7.10 q/ha during 2011 and $6.8 \mathrm{q} /$ ha during 2012) in control as compared to chlorpyriphos $20 \mathrm{EC}+\mathrm{PM}-4+$ captan treatment $(20.20 \mathrm{q} / \mathrm{ha}$ during 2011 and $19.80 \mathrm{q} / \mathrm{ha}$ during 2012) which ranked at first place. The seed treated with imidacloprid $17.8 \mathrm{SL} 7 \mathrm{ml} / \mathrm{kg}$ seed also produced good yield in both the years and was rated as second best treatment followed by chlorpyriphos + Bacillus thurengiensis + captan. Parakhia and Akbari (2004) recorded increased groundnut yield in treatment with fungicide (thiram) and antagonists (Pseudomonas sp. and Bacillus) used to control collar rot disease. In a study on the control of white grub in groundnut, seed treatment with imidacloprid 200 SL@3 ml $/ \mathrm{kg}$ seed resulted in higher yield (20.93 q/ha) against control where the yield was $9.68 \mathrm{q} / \mathrm{h}$ (Singh et al., 2012).

\section{Conclusion}

It can be concluded from the study that seed treatment with Chlorpyriphos 20 EC @ 25 ml $/ \mathrm{kg}$ seed + PM-4@ $10 \mathrm{ml} / \mathrm{kg}$ seed + captan@ @ g/kg seed can be a better approach for integrated management of white grub and collar rot along with improved yield of groundnut ( $20.20 \mathrm{q} / \mathrm{ha}$ in 2011 and $19.80 \mathrm{q} / \mathrm{ha}$ in 2012). The per cent cummulative mortality due to white grub was 1.20 and 1.50 and due to collar rot 0.3 and 0.7 during 2011 and 2012, respectively in this treatment. Chlorpyriphos 20 EC@25 ml / kg seed + Bacillus thurengiensis@ $10 \mathrm{ml} / \mathrm{kg}$ seed + captan@3 g/kg seed can be other option (per cent cummulative mortality due to white grub 1.75 and 1.90 and due to collar rot 0.3 and 0.7 with yield $18.20 \mathrm{q} / \mathrm{ha}$ and $18.50 \mathrm{q} / \mathrm{ha}$ in 2011 and 2012). Imidacloprid 17.8 SL @ $7 \mathrm{ml}$ also provided promising control of both the menaces. 
Table 2. Effect of different treatments with amendments, insecticides, bio-control agents and fungicide on yield of groundnut.

\begin{tabular}{|c|c|c|}
\hline \multirow[t]{2}{*}{ Treatment/Dose } & \multicolumn{2}{|c|}{ Yield (q/ha) } \\
\hline & 2011 & 2012 \\
\hline Chlorpyriphos 20EC, $25 \mathrm{ml} / \mathrm{kg}$ seed $\left(\mathrm{T}^{1}\right)$ & $12.00(28.56)$ & $11.30(19.50)$ \\
\hline Quinalphos 25 EC, 25 ml/kg seed $\left(T^{2}\right)$ & $16.00(24.17)$ & $16.20(23.70)$ \\
\hline Poultry manure, $5 \mathrm{t} / \mathrm{ha}$ (half decomposed) $\left(\mathrm{T}^{3}\right)$ & $12.40(20.57)$ & $12.60(20.73)$ \\
\hline Poultry manure, $5 \mathrm{t} / \mathrm{ha}$ (fully decomposed) $\left(\mathrm{T}^{4}\right)$ & $12.00(20.22)$ & $12.10(20.31)$ \\
\hline Nimbecidine $0.03 \%, 20 \mathrm{ml} / \mathrm{kg} \operatorname{seed}\left(\mathrm{T}^{5}\right)$ & $7.80(16.17)$ & $8.10(16.49)$ \\
\hline Pseudomonas maltophila- $4,10 \mathrm{ml} / \mathrm{kg} \operatorname{seed}\left(\mathrm{T}^{6}\right)$ & $14.10(22.02)$ & $12.50(20.61)$ \\
\hline Rhizobium $\mathrm{GN}-1,10 \mathrm{ml}\left(\mathrm{T}^{7}\right)$ & $7.60(15.92)$ & $7.30(15.64)$ \\
\hline Pseudomonas fluorescens, $10 \mathrm{ml} / \mathrm{kg} \operatorname{seed}\left(\mathrm{T}^{8}\right)$ & $10.50(18.85)$ & $9.50(17.91)$ \\
\hline Bacillus thuriengesis, $30 \mathrm{ml} / \mathrm{kg} \operatorname{seed}\left(\mathrm{T}^{9}\right)$ & $9.20(17.63)$ & $8.20(16.61)$ \\
\hline Chlorpyriphos $+\mathrm{BT}+$ Captan, $25 \mathrm{ml}+10 \mathrm{ml}+3 \mathrm{~g} / \mathrm{kg} \operatorname{seed}\left(\mathrm{T}^{10}\right)$ & $18.20(25.21)$ & $18.50(25.41)$ \\
\hline Chlorpyriphos $+\mathrm{PM}-4+$ Captan, $25 \mathrm{ml}+10 \mathrm{ml}+3 \mathrm{~g} / \mathrm{kg} \operatorname{seed}\left(\mathrm{T}^{11}\right)$ & $20.20(26.67)$ & $19.80(26.36)$ \\
\hline Imidacloprid $17.8 \mathrm{SL}, 5 \mathrm{ml} / \mathrm{kg} \operatorname{seed}\left(\mathrm{T}^{12}\right)$ & $15.70(23.30)$ & $14.70(22.50)$ \\
\hline Imidacloprid $17.8 \mathrm{SL}, 7 \mathrm{ml} / \mathrm{kg} \operatorname{seed}\left(\mathrm{T}^{13}\right)$ & $18.60(25.52)$ & $18.70(25.55)$ \\
\hline Chlorpyriphos $20 \mathrm{EC}, 5 \mathrm{l} / \mathrm{ha}\left(\mathrm{T}^{14}\right)$ & $14.40(22.25)$ & $14.00(21.93)$ \\
\hline Captan, $3 \mathrm{~g} / \mathrm{kg} \operatorname{seed}\left(\mathrm{T}^{15}\right)$ & $14.80(22.65)$ & $14.60(22.30)$ \\
\hline Control $\left(\mathrm{T}^{16}\right)$ & $7.10(15.42)$ & $6.80(15.07)$ \\
\hline S. Em. \pm & 0.82 & 0.59 \\
\hline $\mathrm{CD}(\mathrm{P}=0.05)$ & 2.37 & 1.73 \\
\hline
\end{tabular}

Values in parentheses are angular transformed values.

\section{REFERENCES}

Anitha, V., Wightman J. and Rogers, D.J. (2005). Management of White grubs (Coleoptera: Scarabaeidae) on groundnut in southern India. Int. J. Pest Manag., 51: 313-320

Anonymous (2009). Package of practices for Kharif crops. CCS Haryana Agricultural University, Hisar. pp 231.

Anonymous (2016). Annual report (Kharif 2015) of groundnut. Junagarh Agricultural University, Junagarh. 2 p.

Atwal, A.S. and Dhaliwal, G.S. (2010). Agricultural Pests of South Asia and their Management. Kalyani Publishers, New Delhi. pp 616.

Chaudhary, O.P. and Dashad, S.S. (2002). Effectiveness of insecticides against white grub and their deleterious effects on germination in perlmillet. Crop Res., 23: 247252

Gangopadhyay, S., Bhatia, J. N. and Godara, S.L. (1996). Evaluation of fungicides for the control of collar rot of groundnut. J. Mycol. Pl. Pathol., 26: 278-279

Gangwar, R.K., Bhatnagar, Ashok., Sharma, R.K. (2015). Management of white grub in groundnut growing under arid and semi-arid regions of India. Res. on Crops., 16: 728-733

Jain, A.C. and Nenra, K.G. (1952). Aspergillus blight of groundnut seedlings. Sci. Cult., 17: 348

Jetiyanon, K. and Kloepper, J.W. (2002). Mixtures of plant growth-promoting rhizobacteria for induction of systemic resistance against multiple plant diseases. Biol. Control.

\section{4: $285-291$}

Karthikeyan, A. (1996). Effect of organic amendments, antagonist Trichoderma viride and fungicides on seed and collar rot of groundnut. Pl. Dis. Res., 11: 72

Meena, N.L. and Gangwar, R.K. (2011). Management of collar rot of disease of groundnut by seed treatment with vitavax power. Pestology. XXXV: 26-28.

Parakhia, A.M. and Akbari, L.F. (2004). Integrated control of collar rot (Aspergillus niger) in groundnut. J. Mycol. Pl. Pathol., 34: 289-290

Raj Kumar, V. and Raja, J. (2007). Effect of poultry litter soil amended on Macrophomina phaseolina in sunflower. J. Mycol. Pl. Pathol., 37: 171.

Rakholiya, K.B., Jadeja, K.B. and Parakhia, A.M. (2012). Management of collar rot of groundnut through seed treatment. Int. J. Life Sci. Pharma Res., 2: 62-66

Singh, Swaroop., Bhatnagar, S.A. and Ahuja, D.B. (2012). Bioefficacy of insecticides as seed dresser against white grub Holotrichia consanguinea Blanchan in groundnut. Indian J. Ent., 74: 24-26

Sharma Sushil and Mehra Rakesh (2014). Mnagement of collar rot of ground nut caused by Aspergillus niger. Pl. Dis. Res., 29: 93-94

Theurkar, S.V., Ghadage, M.K., Madan, S.S., Bhor, G.L.and Patil, S.B.(2013). Occurrence of white grubs in ground nut growing area of Khed Taluka, part of Northern Western Ghats, MS India. Res. J. Recent Sci., 2: 1-3 